\title{
Comparative Study of Quality Assurance Practices in Unity Schools and Private Secondary Schools in Kwara and Oyo States, Nigeria
}

\author{
Olatunde Olaide Atanda ${ }^{\mathrm{a}, *} \&$ Adeseko Sunday Olaifa ${ }^{\mathrm{b}}$ \\ ${ }^{a}$ Department of Business, Atlantic Hall, Lagos, Nigeria \\ ${ }^{b}$ Department of Educational Management and Counselling, Al-Hikmah University, Ilorin, Nigeria
}

\begin{abstract}
This paper compared the quality assurance practices in Unity and private secondary schools in Kwara and Oyo States, Nigeria. The research design employed for the study was a descriptive survey type. The population of the study was made up of all Unity and Privates secondary schools in Kwara and Oyo States, Nigeria. Purposive and random sampling techniques were used to select the respondents in all the sampled schools. The data for the study were gathered through the use of questionnaires tagged "Quality Assurance Practices Questionnaire" (QAPQ). The data gathered during this study were analyzed with inferential statistics called ttest and ANOVA. The findings revealed that there is a difference in the quality assurance practices between the sampled school. Private secondary schools in Kwara and Oyo State were rated higher than the Federal Government Colleges. This paper further revealed that the discipline and control of staff in private secondary schools in Kwara and Oyo States were stricter than the Federal Government Colleges in both States.
\end{abstract}

Keywords: Quality Assurance Practices; Infrastructural Facilities; Staff Discipline; Unity Schools; Private Schools.

\section{Introduction}

Quality Assurance in Nigeria has metamorphosed from the former practice of mere school inspection to a more sophisticated process of monitoring and evaluating operative mode of the school. It ensures that the process and practice of school evaluations are carried out in line with the set standards and procedures that bring about improvement in outcomes for the learners (FME, 2016). The same quality standards and indicators are used in the process of external and internal evaluations and are made known to all stakeholders. The findings are usually valid, much more reliable and are very consistent. This eventually encourages state and national planning, training and policy developments in the country (FME, 2016).

Education has been considered as important transformational tool of change in any society and in national development. Quality of the human and material resources of a country depends to a greater extent on the development and quality of the country's level of education (Alumodi, 2005). Education has been pivotal in developing human potentials positively, it also helps in developing human talents, intellect, attitude and skills. Education is the essential contributor to the development of individual as it increases human productivity and also facilitates participation in their economic and societal lifecycle (Aworanti, 2012). Federal Republic of Nigeria (FRN, 2004) suggested that raising the quality of education at all level to make the end products of the system more useful to the society and to maintain education as one of the prime instrument for development is the main policy objectives of education in Nigeria. It is worthy to note that the outcome of educational learning carried out is evidenced in its quality (Adams, 2011). There is every likelihood that education will lose out to nothing else unless there is a quick transformation of excellence and functionality in the system. Regrettably, the present level of education in Nigeria is not of an acceptable normal in quality and its functions (Babalola, 2004). Even though educational has been regarded as an instrument of change, most people nowadays participate for them to just have a formal prove; as their end goal is to join politics and possibly become parts of the bandwagon in looting public funds. It's no longer news that Nigerian politics is unarguably the most profitable venture and this has captured the interest of everyone. The extinction of quality and functionality in the Nigerian educational system was supplementary assisted by struggle to

* Corresponding author.

E-mail address: olaatanda3004@gmail.com 
acquire any certificate as a stepping stone to fine tune their prospects in politics. Against all these, (Kadir, 2012) as quoted by (Adegbesan, 2010) discerned that standardization of quality needs to be reestablished and assured in the Nigerian educational system. In the same vein, (Kadir, 2012) suggested that Nigeria will need to get it right in terms of ensuring quality education like their Russian counterpart whose educational standard has been the "magic wand" that metamorphosed their country in the year 1913 from an extremely regressive state of a nation with povertystricken economy into one of the world's most advanced country in technology and economy. Furthermore, (Mungle, 2013) as quoted by (Adegbesan, 2010) validated the need to have standard in education, opined that quality and standard in education is also the known-secret that metamorphosed Japan into the third most industrialized nation on the planet earth. Having observed all these, one would not be wrong to conclude that standardization in the Nigerian educational system should be engineered towards the developments of knowledge, ethical values, skills and positive behaviors of the beneficiaries with more importance given to the applicability of the training to such beneficiaries in particular and the entire Nigerian society as a whole.

\subsection{Unity and Private Schools in Nigeria}

Unity schools are otherwise known as Federal Government Colleges and private secondary schools are supposed to be well funded by the respective owners. They are to possess quality management with highly trained personnel, moral discipline, ethical managerial practices. With all the quality input, one can believe that they should have what it takes to deliver good quality education and hence, societal expectations are high. From the historical perspective of schools in Nigeria, Unity schools came into existence in 1967 and were the fallout of the Biafra war. But from all indications, these schools no longer serve the purpose for which they were established. Federal Government Colleges were established by the Federal Government of Nigeria as an exemplary attempt to promote much-needed acceptability, loyalty and one united people among the conflicting communities through education. The establishment of these schools was rightly orchestrated to be the fastest and best means of promoting understanding, tolerance and respect for one another's culture especially after the civil war; and children in their early years were allowed to live together especially in a place other than that of their localities with a probable opportunity to learn new things about the culture of other tribes to build their tolerance and patriotic spirit towards national unity. One other idea considered by the government before establishing Unity schools was predicated on the need to foster unity among Nigerian youths through education. But the confusion now is that many Nigerians are complaining that the Unity schools are no longer leaving up to its expectation as a result of mismanagement of these schools. But recently, a lot of issues have come to condemn the policy, prompting many Nigerians to question the relevance of their continuing existence. Over time, allegations of various wrongdoings ranging from outright embezzlement of funds to admission racketeering among managers of these schools and their collaborators have generated a lot of controversies. Admission processes and the way and manner it has been handled by the managers of these schools in recent time have called for questions as it was no longer based on merits, but whom you know. Many have criticized that the common entrance examinations conducted every year for admission of students were just for formality. The usually strict admission policy and procedures from the inception were no longer followed, as there were allegations of corruption here and there in the system. Recent investigation showed that few students who believed that their admission processes was marred with cheating made formal complaints. In all these, one thing is sacrosanct that whenever the history of manpower development in Nigeria is written, the Unity schools will not be exempted because they came in at the expedient time when the country was just developing indigenous manpower to replace the colonial masters. As of today, many stakeholders have argued that the quality standard and popularity of these unity schools are vanishing. As observed by stakeholders, while few of these schools are still maintaining their academic excellence, others are struggling to preserve relevance. The reason may not be far from the fact that many Nigerians are not ready to either do things right or do the right thing.

Moreover, abnormalities have bedeviled these schools across the country; the purpose for which the schools were established has been defeated. The academic performance of these students has deteriorated to the extent that if they are confronted with external examinations they would perform below expectations. Many a time, people wonder what has gone wrong to warrant the embarrassing tumble of these schools and the contempt to which Nigerians hold them. The biggest problems of these schools lie in the way and manner students are admitted; and except the government address the issue urgently, it will degenerate to the total collapse of the noble idea. Admissions provisions are made from irritating issues like catchment area, state of origin, and minister's quota; director general's quota, members of the National Assembly quota, principal's quota among others. Merit, which is supposed to be the overriding factor in admission, has been relegated to the background. Meritocracy should never be sacrificed on the altar of mediocrity; otherwise, the nation will continue to slide back. Unity schools should be regarded as centers of excellence where 
only the best should be found, and not an all-comers affair where the major consideration for admission is where a pupil hails from or whom his/her parents know. However, notwithstanding the array of public and Unity schools, private schools have been on the rise at all levels of education in Nigeria. The contributing factors to this include gross negligence and poor funding of public schools by various governments, derision action of teachers characterized by irregular payment of wages as well as low pay for tutors. These resulted in constant industrial action by teachers leading to irregular academic activities. As a result, private schools sprang to serve as stiff competitors to correct those anomalies in the public. It is no surprising that presently in some states, the available private primary and secondary schools greatly outnumber the public or government schools. Despite the bogus fees charged by private schools, they are still preferred over the public schools that are relatively free. This is just because private schools do not involve themselves in industrial actions that have always led to interferences in the academic calendar of public schools.

In Nigeria, the missionaries as early as the mid-nineteenth century started the European-style schools, by using them as instruments for evangelism. The education in these schools revolved around religion, although they still exist quite a few private schools that have their foundations in the gospel, the curricula have expanded to include broader, secular topics like vocational skills and sport. The qualities of education in private secondary schools are unsurprisingly high, and students need not worry about failing, teachers not being paid or strike action, the inadequacy of facilities, or underfunding. This is because many of these private secondary schools are well equipped with state-of-the-art facilities, and offer a healthy choice of extra-curricular activities to make the recipient a total child. Although we still have these schools in categories, while some are standard, others are substandard. Assessing most of the public schools one would see that the learning environment has woefully deteriorated; many of the old government schools no longer have fittings and in so many cases worn-out buildings. The pertinent question is how many parents can afford private schools? Schools have been commercialized in the country. Recent statistics show that majority of the old public secondary schools in Nigeria have been neglected with dilapidated buildings. Classes in some schools are mostly held under trees. The quality of lessons conducted under such an inhumane condition can never be anything that a reasonable person will be proud of.

With the proliferation of secondary schools in the late 1980s during the military rule of General Ibrahim Babangida, Boarding School System came to a state of collapse and this led to a general downtrend in the quality of education provided in our secondary schools. Every community began to set up her schools without considering where and how to get money and qualified teachers to maintain them. To compound the situation, the private sector took advantage of this and began to set up private secondary schools to provide the necessary boarding facilities which are now lacking. These emerging private schools were highly commercialized and they were unbearable to the masses. There is a need to first clarify that in Nigeria of today, there are many mushrooms, grossly sub-standard and ill-equipped secondary schools set up by hungry proprietors in the private sector. In describing these mushroom secondary schools, (Sunday Tribune editorial, 2008) declared there as of the late 1980s there were only a few private schools in the country. Even a struggling carpenter can now afford to sends their children to a private school comfortably. The mushrooming and proliferation of private schools has resulted in the falling standard of these schools in so many areas. The buildings used by some of the schools especially for nursery and primary education are usually the private property of the owner, most of the time are not originally designed to accommodate a school. The majority of their teachers are not experienced or not qualified at all. The remuneration is poor and this puts more pressure on the parents who are already hard-pressed. The primary aim of the owners of these schools is to make a quick profit in the business thereby reducing their direct investment into the venture.

\subsection{Quality and Quality Assurance in Nigeria Secondary Schools}

The motivating forces for reforms of education falling standard in Nigeria are the concern of every stakeholder. Quality is seen as the total characteristic of a process, product, or service on its performance. It is not just a feature given standard of a finished product or services but involves a focused standard on internal processes and also outputs which give no room for wastage and also encourage enhancement or efficiency (Ajayi \& Adegbesan, 2007). From the definition above, quality can be branded into three inter-related and inter-dependent components by (Fadokun, 2005) as:

a. The efficiency of production in the achievement of its objectives.

b. The importance of the production to human and environments and needs.

c. Assessment of new ideas, the hunt of brilliancy and reassurance of originality in the course of further production. 
Quality of Education is arbitrated from an outcome perspective; in which he believed that quality must have the capacity to make recipients perform excellently in a standardized assessment that is important to needs of the tutors and the society in general (Arikewuyo, 2004). In the same vein, quality assurance is linked to responsibility connected to maximizing the usefulness and efficacy of educational systems and services relatively to their contexts, missions and goals (Ajayi \& Adegbesan, 2007).

Ehindero, (2004) concludes that quality assurance concentrated as follows:

a. The students' entry behaviors - moral upbringing that can prevent or enable learning including some demographic factors

b. The teacher entry qualification- all values and pedagogic skills that can facilitate teaching such as teacher's qualifications, subject mastery, and ethical alignment etc.

c. The learning processes- this involves the contact between learners and tutors. The organisation of the curriculum and learning environment are inclusive.

d. The results- This can be of skills, attitudes and knowledge, including appropriate and relevant instruments to assess these goals.

As identified by UNICEF, quality assurance oriented schools are characterized by core values and elements like quality learners, qualified and experienced teachers, conducive learning environments, adequate curriculum content, effective and efficient learning processes, and quality learning results (UNICEF, 2000). Quality Assurance in Nigeria values according to Federal Ministry of Education, (2010) are categorized into seven thematic areas namely: quality of infrastructure and learning environment; good curriculum and other related activities; good teaching and learning; adequate care, guidance and support; good learners' skills and participation; measurable achievement and standards; and good leadership and management

Pursuing the goal of ensuring quality education in the Nigeria educational system, the commitment-holders will have to maintain a very strong and close exchange of information, collaboration and reliable synergy with the school administrators. Furthermore, contribution of enough resources to make sure that the school remains on-track must be done by them as this will undoubtedly lead to an effective implementation of the curriculum to achieve the desired learning results. Whenever the school is not fulfilling its purpose by living up to the desire expectations, the stakeholders have to intervene by reviewing, restructuring, and refocusing the management strategies on the prevention of defects in the transformation process so that quality education will be ensured to enable students that do not perform well achieve the good learning outcome.

\section{Methodology}

This study is descriptive in nature, the research technique provides the golden opportunity to look into the comparison of quality assurance practices between Unity and private secondary schools in Kwara and Oyo States. This study covered two States from two geo-political zones of the country. They are Kwara State from the North Central and Oyo State South-West Nigeria

The population used in Oyo State comprised the 257 private secondary schools in the 33 Local Government Areas. Stratified random sampling technique based on the exiting three senatorial districts in the state was used to sample 13 Local Government out of the 33 Local Government Areas which constituted 39\% and 22 schools. The population used in Kwara State comprised all the 171 private secondary schools in the 16 Local Government Areas. Stratified random sampling technique based on the exiting three senatorial districts in the state was used to sample 6 Local Government out of the 16 Local Government Areas which constituted 39\% and 67 schools.

There are 104 Unity schools (Federal Government Colleges) in Nigeria; four out of them in the two States were purposively selected for the study. They are

- Federal Government Girls College Omu Aran, Kwara State

- Federal Government College Oloje Ilorin, Kwara State

- Federal Government College Ogbomoso, Oyo State

- Federal Government College Oyo, Oyo State 
In total, 89 private secondary schools and 4 Federal Government Colleges were selected for the study from Kwara and Oyo States. A total number of 700 questionnaires were distributed among 89 schools out of which 595 were successfully completed and returned representing $85 \%$.

The study data were collated through the use of questionnaires. Questionnaire tagged "Quality Assurance Practices Questionnaire" (QAPQ) was administered to teachers, vice principals and principals.

\section{Research Hypotheses}

$\mathrm{HO}_{1}$ : There is no significant difference in the quality of infrastructural facilities in Unity and private secondary schools in Kwara and Oyo States

$\mathrm{HO}_{2}$ : There is no significant difference in the mode of staff discipline in Unity and private secondary schools in Kwara and Oyo States

$\mathrm{HO}_{3}$ : There is no significant difference in the quality assurance practices in Unity and private secondary schools in Kwara and Oyo States

\section{Results}

The data gathered during this study were analyzed with inferential statistics. An inferential statistic of ANOVA was used to test the main hypothesis and t-test was employed to test the two operational hypotheses formulated at 0.05 alpha level of significance. Decisions were taken electronically using a calculated significant level against a critical significant level of 0.05 .

H01: There is no significant difference in the quality of infrastructural facilities between Unity schools and private secondary schools in Kwara and Oyo States

Table 1. The result of t-test on the quality of infrastructural facilities between unity and private Secondary schools in Kwara and Oyo states

\begin{tabular}{|c|c|c|c|c|c|c|c|}
\hline Variables & $\mathbf{N}$ & $\mathbf{x}$ & SD & Df & $\begin{array}{l}\text { Cal t-test } \\
\text { value }\end{array}$ & $\begin{array}{l}\text { Cri t-test } \\
\text { value }\end{array}$ & Decision \\
\hline Unity Schools & 159 & 13.4 & 5.09 & & & & \\
\hline $\begin{array}{l}\text { Private } \\
\text { Schools }\end{array}$ & 436 & 13.9 & 5.15 & 593 & 3.89 & 1.96 & H0 Rejected \\
\hline
\end{tabular}

Table 1 showed that the calculated t-value of 3.89 is greater than the critical t-value of 1.96 at 0.05 level of significance at 593 degrees of freedom. Thus, the null hypothesis which states that there is no significant difference in the quality of infrastructural facilities between Unity and private secondary schools in Kwara and Oyo States was rejected. Therefore, the alternative hypothesis that states there is a significant difference in the quality of infrastructural facilities in Unity and private secondary schools in Kwara and Oyo States was accepted. While Federal Government Colleges in Kwara and Oyo States had a mean score of 13.4, private secondary schools in both States had a mean score of (13.9) which represents the gap between the two schools. From the findings in Table 1, the provision of infrastructural facilities in Unity and private secondary schools in Kwara and Oyo States were significantly different. Facilities such as ICT, physical condition of classrooms, security/environment, health services, water, electricity and transportation in private secondary schools were higher than in Unity schools in both Kwara and Oyo States.

\section{$\mathrm{HO}_{2}$ : There is no significant difference in the mode of staff discipline in Unity schools and private secondary schools in Kwara and Oyo States}

Table 2 showed that the calculated t-value of 3.46 is greater than the critical t-value of 1.96 at 0.05 level of significance at 593 degrees of freedom. Thus, the null hypothesis which states that there is no significant difference in the mode of staff discipline in Unity and private secondary schools in Kwara and Oyo States was rejected and the alternative that states that there is a significant difference in the mode of staff discipline in Unity and private secondary schools in Kwara and Oyo States was accepted. While Unity schools in Kwara and Oyo States had a mean 
score of (11.7), private secondary schools had a mean score of (15.6). This infers that the staff discipline in Unity schools are not the same as private secondary schools in Kwara and Oyo States. The justification for this is shown from table 2; all the disciplinary tools such as the use of verbal and warning query, warning letters, suspension without pay, suspension with pay and sack without prior notification are more used in private secondary schools than Unity schools in Kwara and Oyo States. This makes staff discipline secondary schools firmer than Unity schools in Kwara and Oyo States.

Table 2. Results of $\mathrm{t}$ - test on the mode of staff discipline in between Unity schools and private secondary schools in Kwara and Oyo States

\begin{tabular}{lrcccccc}
\hline Variables & $\mathbf{N}$ & $\mathbf{X}$ & $\mathbf{S D}$ & df & $\begin{array}{c}\text { Cal t- test } \\
\text { value }\end{array}$ & $\begin{array}{c}\text { Cri t-test } \\
\text { value }\end{array}$ & Decision \\
\hline Unity Schools & 159 & 11.7 & 6.78 & & & & \\
& & & & 593 & 3.46 & & H0 Rejected \\
$\begin{array}{l}\text { Private } \\
\text { Schools }\end{array}$ & & & & & & & \\
\hline
\end{tabular}

H03: There is no significant difference in quality assurance practices in Unity and private secondary schools in Kwara and Oyo States

Table 3. The result of ANOVA on the quality assurance practices in Unity and Private secondary schools in Kwara

\begin{tabular}{lclccrr}
\multicolumn{1}{c}{ and Oyo States } \\
\hline \multicolumn{1}{c}{ Variables } & SS & Df & MS & F & Significance & Decision \\
\hline $\begin{array}{l}\text { Between } \\
\text { Group }\end{array}$ & 1002.44 & 2 & 1003.44 & & \\
Within Group & 306858.52 & 593 & 771.24 & 4.340 & 3.000 & H0 Rejected \\
Total & 307860.96 & 595 & & & \\
\hline
\end{tabular}

From Table 3, it is evident that differences exist between the quality assurance management in Unity and private secondary schools in Kwara and Oyo States since the calculated f-value of 4.340 is greater than the significant value of 3.000 at 0.05 level of significance. Based on the findings, the null hypothesis which states that there is no significant difference in the quality assurance practices in Unity schools and private secondary schools in both Kwara and Oyo States was rejected. Thus, the alternative hypothesis that states that there is a significant difference in the quality assurance practices in Unity and private secondary schools in both Kwara and Oyo States was accepted. Findings in the study revealed that the quality assurance practices in private secondary schools in Kwara and Oyo States are more rated than the quality assurance practices in Unity schools in the States. This is probably due to the ownership and the managerial set up of private secondary schools which make supervision and inspection strict. Moreover, it also allows private secondary schools to uphold the quality of their standard which is one of the major reasons why parents prefer private secondary schools than public schools. However, it is important to note that some private schools in Kwara and Oyo States were rated highly in terms of infrastructure, punishment, and good school environment while others are usually poorly rated and scarcely sought after because they exhibit those characteristics that neither promote excellence in learning nor make a contribution to education delivery.

\section{Discussion of Findings}

Hypothesis one which stated that there is no significant difference in the quality of infrastructural facilities in Unity and private secondary schools in Kwara and Oyo States. The finding revealed that the respondents indicated that private secondary schools are rated higher than Unity schools in Kwara and Oyo States in the provision of facilities. The researcher assumes that this is one of many major considerations why most parents enrol their children in private secondary schools without minding whether the so-called private secondary schools have active resources. From the observation of the researcher during the administration of the instrument, quality of equipment and infrastructures in some private secondary schools especially the legit international schools were more rated higher than Unity schools in both States. Although, Unity schools in Kwara State were better maintained despite the long age of establishment than 
Unity schools in Oyo States. Unity schools were lacked infrastructures such as furniture and fitting fort students, derelict buildings, however, the flipped was the story in most private secondary schools visited by the researcher. This research result was validated through Babalola (2004) study on learning and resource materials in schools that on one hand, some good school facilities can complement a well-planned programme and on the other hand, an ailing infrastructure can cripple an outstanding school program even with resourceful tutors. This was buttressed by Omotosho (2008) which stated that the education problem in any nation is a function of worsening circumstances within the school in respect of teaching facilities, physical learning resources, the well-being of teachers and the outrageous levy of education.

Hypothesis two which stated that there is no significant difference in the mode of staff discipline in Unity schools and private secondary schools in Kwara and Oyo States examined tutors' discipline in the study revealed that tutors' dedication and excellence determines the schools' efficiency. The educators are at the centre of any educational system. Otherwise stated, no citadel of learnings can be better than the quality of their tutors. In the study of Paln and Bodunde (1999), it was revealed that educators as role models are expected to be an exemplary leader for students in their care, unfortunately the act of teachers' indiscipline is predominant today. Most educators in Unity schools lack work genuineness and dedication to duty; thus rendering the school administration ineffective. This justification was made from the experience of the researcher during the period of distribution of questionnaires in a particular Federal Government College; teachers were already gone before the normal closing time of 2:00 pm. As a result, the researcher was forced to revisit the particular school the following day. But one may ask, what gave the teachers the confidence to leave the school before the official time? In private secondary schools, permission to leave your place of duty cannot be granted easily unless it passes through tough scrutiny from your superiors. The mode of discipline in Unity schools takes time and a longer route while that of private secondary schools is instant. This makes the mode of discipline in Unity schools not as strict compared to private secondary schools.

\section{Conclusions}

Base on the findings of the study, the following conclusion were made: Private secondary schools in Kwara and Oyo States were rated higher than Unity schools in Kwara and Oyo States in terms of infrastructures and equipment such as laboratory equipment, furniture in classrooms, well-equipped clinics and efficient transportation system. Staff discipline is stricter and firmer in private secondary schools than Unity schools in Kwara and Oyo States. It was evident from the findings that the approach to discipline in private secondary schools is different from Unity schools. To teach in private schools, work regulations are clearly stated before signing the employment. By implication, one an educator signs the employment contract, such educator is bound to accept the terms of the contract such as penalties for violation of the school's discipline code. However, in Unity schools, you have rights - constitutional rights that must be respected. The disciplinary process is time consuming, commonly burdensome and complex procedure especially if the teacher in question has a god-father.

Based on the findings in this study, the following recommendations were made:

1. The private secondary school should intensify the improvement of their schools. Moreover, the Federal Government of Nigeria should also pay rapid attention to the decaying state of infrastructural facilities in Unity schools. This is necessary because of fast fluctuations in the society and deteriorating quality of educational outputs.

2. The discipline of staff should be holistic especially in Unity schools. There should be a periodic purposeful, systematic, problem-solving, diagnostic honest and comprehensive appraisal of the declining quality of secondary schools in Kwara and Oyo States and erring schools whether government funded or private should be re-organised. Also, both schools should melt out appropriate punishment and sanctions to erring staff and appraise those that are of good behaviour

\section{References}

Adams, B. (2011). Human resources as the wealth of Nations. New York: The free press.

Adegbesan S. O. (2010). Establishing quality assurance in Nigerian education system: Implication for educational managers. National Institute for Educational Planning and Administration (NIEPA), Akure, Ondo State, Nigeria. Educational Research and Reviews 5 (7), 380-384. 
Adegoke, K. A. (2003). Curriculum theorizing for competency. An inaugural lecture delivered at University of Lagos. University of Lagos Press.

Ajayi, T. \& Adegbesan, S. O. (2007). Quality assurance in the teaching profession. Paper presented at a forum on emerging issues in teaching professionalism in Nigeria, 14-16 Akure, Ondo State.

Alumodi, B. E (2005). Enrolment patterns and teacher adequacy in Ebonyi state, secondary schools. An unpublished Ph.D Thesis. Department of Educational Foundations, Faculty of Education, Ebonyi State University, Abakaliki.

Arikewuyo, M. O. (2004). Effective funding and quality assurance in the Nigerian education system. A paper presented at the 1st National Conference of the Institute of Education, Olabisi Onabanjo University, AgoIwoye Jan. 12-15.

Aworanti, O. A (2012) Quality assurance in business education. A lead paper presented at the 24th Annual National Conference organized by the Association of Business Educators of Nigeria at Federal Polytechnic, Nekede Owerri, Imo state; 16th-20th October.

Babalola, J. B. (2004). Quality assurance and child friendly strategies for improving public school effectiveness and teacher performance in a democratic Nigeria. In E. O. Fagbamiye; J. B. Babalola; M. Fabunmi; \& A. O. Ayeni. (eds.) Management of primary and secondary education in Nigeria. Ibadan. NAEP 303-312.

Ehindero, S. (2001). The pitfalls of UPE and the need to enhance quality in the implementation of Universal Basic Education. Paper presented at the National workshop on Universal Basic Education (UBE) organized by the Faculty of Education, University of Ilorin.

Ehindero, S. (2004). Accountability and quality assurance in Nigerian education. Paper presented at the International conference of the Institute of Education, Olabisi Onabanjo University, Ago - Iwoye.

Fadokun, J. B. (2005). Educational assessment and quality assurance implication for principal instructional leadership roles. Paper presented at the 31st Annual Conference of International Association for Educational Assessment 4-9, September, Abuja.

Federal Ministry of Education (2010). Education Quality Assurance Handbook for Nigeria. Abuja: Federal Inspectorate Services. 2010.

Federal Ministry of Education (2016). Education Quality Assurance Handbook for Nigeria. Abuja: Federal Inspectorate Services. 2016.

Federal Republic of Nigeria (2004). National Policy on education (4th ed) Lagos: Nigerian Educational Research and Development Council.

Ijaiya, N. Y. S. (1991). Practicum-based supervision in teacher education. Journal of the Federal Ministry of Education. 11(3)38-41.

Ijaiya, N. Y. S. (2000). From quality control to quality Assurance: A panacea for quality education in Nigerian schools. A Journal of the Nigerian Association of Educational Administration and Planning. 295 - 303.

Kadir, M. (2012). Quality assurance in Nigeria tertiary education. Seminar paper presented at Ahamadu Bello University Zaria.

N.P.E (2004): National Policy on Education. Federal Republic of Nigeria fourth edition.

Mungle, C. (2013). Inspection, education and quality assurance. Washington D.C U.S.A, Department of Education. Office of Educational Research and Improvement.

Ojedele, P. K. (2007). Vocational and technical education in Nigeria: Issues and challenges. Paper presented at the international conference of the Nigerian association for educational management administration and planning (NAEP). University of Lagos 9, 24-27.

Omotoso, M. O. (2008). Private sector and university education system in Nigeria. A review and synthesis in M. Boucouvalas and R. Aderinoye (eds) Spectrum books limited Ibadan. (2) $512-527$.

Onocha, C. O. (2002). Quality assurance in teacher education. A discussion paper presented at the NTI's 25th anniversary celebration, Kaduna. 
Paln, D. Z. \& Bodunde, H. A. (1999). An overview of examination malpractices in Nigerian education system. In S. I. Okoli \& L. U.Ezeani Education in Nigeria: A critical analysis. Onitsha, Lincel publishers. 96-106.

United Nations International Children's Fund, (2000). Curriculum report card. Working paper series, Education Section Programme Division. New York.

United Nations Educational Scientific Cultural Organization (2000). The State of education in Nigeria, Abuja. Heinemann educational books Nigeria limited.

West-Burham, J. (1994). Inspection, evaluation and quality assurance. In T. Bush and J. West-Burnham (eds). The principles of educational management. 157 - 176. Harlow, Longman. 